\title{
Pigs with highly prevalent antibodies to human coronavirus and swine haemagglutinating encephalomyelitis virus in the Tohoku District of Japan
}

\author{
N. HIRANO*, Y.SUZUKI AND S. HAGA \\ Department of Veterinary Microbiology, Iwate University, Morioka 020, Japan
}

(Accepted 18 February 1999)

\section{SUMMARY}

From 1985 to 1988 , a total of 2496 swine sera from 60 farms in the Tohoku District of the Honshu Island of Japan were examined for antibodies to swine haemagglutinating encephalomyelitis virus (HEV), human coronavirus (HCV) and bovine coronavirus (BCV) by haemagglutination-inhibition (HI) test. Antibodies to HEV 67N strain and HCV OC43 strain were highly prevalent with positivity rates of 82.1 and $91.4 \%$, respectively, while seropositivity rate to BCV Kakegawa strain was $44 \cdot 2 \%$. No clinical signs of HEV infection were noticed in any farms including farms with relatively high seropositivity. The results suggested that HCV or antigenitically related virus(es) as well as HEV might be perpetuated in swine in the Tohoku District.

\section{INTRODUCTION}

Coronaviruses infect a wide variety of animal species, including avians and humans, causing respiratory disease, enteritis, hepatitis, or encephalitis [1]. Transmissible gastroenteritis virus (TGEV), haemagglutinating encephalomyelitis virus (HEV) and porcine epidemic diarrhoea virus (PEDV) are known, as coronaviruses, to infect porcine species. In 1958, HEV was first reported in Canada to cause vomiting and wasting disease in young pigs and encephalitis in sucklings [2]. Since the virus was first isolated from the brain of an encephalitic pig [3,4], many isolates of HEV have been reported [5-7]. Mortality in suckling piglets ranges from 20 to $100 \%$, while adults are apparently uninfected [3].

Serological surveys revealed that HEV infection in swine is globally very common. In fattening pigs, seropositivities of $31 \%$ in Canada [8], 49\% in England [3], $46 \%$ in North Ireland [9], $41 \%$ in Taiwan [10], $52 \%$ in Japan [11] and $0-89 \%$ in the United States [12] are reported.

* Author for correspondence.
In Japan, Hirai and colleagues [11] first reported that about a half of swine sera were positive for antibodies to HEV by the haemagglutinationinhibition (HI) test, suggesting that the virus apparently exists in swine. In Japan, the virus was first isolated from the respiratory tract of piglets from two farms showing $50 \%$ or more seropositivities [13].

This paper describes the results of a serological survey for HEV, HCV and BCV in 60 swine farms of the Tohoku District.

\section{MATERIALS AND METHODS}

\section{Serum samples}

The sera collected from 2469 pigs 3-7 months of age in 60 farms in Aomori, Iwate, Akita and Miyagi prefectures from 1985 to 1988 and stored at $-20^{\circ} \mathrm{C}$. These sera were heated at $56^{\circ} \mathrm{C}$ for $30 \mathrm{~min}$, and mixed with an equal volume of $25 \%(\mathrm{w} / \mathrm{v})$ kaolin solution in Dulbecco's phosphate-buffered saline (PBS, pH 7·2) at room temperature for $30 \mathrm{~min}$. After centrifugation at $8000 \mathrm{rpm}$ for $10 \mathrm{~min}$, the supernatants were mixed with an equal volume of $10 \%(\mathrm{v} / \mathrm{v})$ chicken red blood 
cell (CRBC) suspension in PBS and were incubated at room temperature for $30 \mathrm{~min}$. After centrifugation at $2000 \mathrm{rpm}$ for $10 \mathrm{~min}$, the treated serum samples were used as $1: 4$ dilution.

\section{Virus strains}

Virus strains used in this test were HEV $67 \mathrm{~N}$ strain (HEV-67N) [7], bovine coronavirus Kakegawa strain (BCV-K) [14] and human coronavirus OC43 strain (HCV-OC43) [15]. HEV-67N and BCV-K were propagated and assayed in SK-K cells [16] and BEK1 cells [17], respectively, as reported previously. HCVOC43 grown in mouse brain was kindly supplied by Dr R. Kawana, Department of Bacteriology, Iwate Medical University.

\section{Mice}

Specific pathogen-free ICR pregnant, and 4-week-old male mice were obtained from Japan SLC (Hamamatsu, Japan), the mice have been determined to be free from murine coronavirus infections by routine serology. The suckling mice were nursed by their dams. The suckling mice and their dams were kept in metal cages with filter caps, and 4-week-old mice were kept in plastic isolators. Animals were given autoclaved commercial pellets and water freely. The animal experiments were performed humanely in accordance with guidelines of animal experimentation of Iwate University.

\section{Virus antigens}

HEV-67N and BCV-K were inoculated into SK-K and BEK-1 cells, respectively, as previously described. Supernatants were collected after cytopathic effect was observed in the infected cell cultures, and stored at $-70{ }^{\circ} \mathrm{C}$ until use. After intracerebral inoculation with HCV-OC43 into suckling mice, the brains were collected from the animals showing clinical signs of infection and were stored at $-70{ }^{\circ} \mathrm{C}$. A $10 \%$ brain homogenate $(\mathrm{w} / \mathrm{v})$ was prepared in PBS and the supernatant was used as antigen after centrifugation at $3000 \mathrm{rpm}$ for $10 \mathrm{~min}$.

\section{Antisera to HEV-67N, HCV-OC43 and BCV-K}

Four-week-old mice were inoculated intraperitoneally twice at an interval of 2 weeks with $0.5 \mathrm{ml}$ of each virus material. At 1 week after last inoculation the mice were killed to collect the blood. The serum was heated at $56^{\circ} \mathrm{C}$ for $30 \mathrm{~min}$ and was used as positive control. Hyperimmune guinea-pig serum against TGEV strain TO-163 had been kindly supplied by National Institute Animal Health (Tsukuba, Japan) was used to check cross reactions among the antisera and viruses.

\section{Haemagglutination (HA) and HI tests}

The tests were performed by the microtitre technique with PBS and $0.5 \%$ CRBC [11]. An HI titre of 8 or higher was recorded as positive because Kaye and colleagues [18] reported that a positive antibody response was determined on the basis of a titre of $\geqslant$ 10. The sera was diluted two-fold from $1: 8$ to $1: 1028$ in PBS and were checked for HI antibodies titres.

\section{RESULTS}

\section{HI antibodies to HEV $-67 \mathrm{~N}$}

As shown in Table 1, 2028 out of $2469(82 \cdot 1 \%)$ sera from 4 prefectures were positive for HEV-67N, showing geometric mean titres (GMT) of 43. In Aomori Prefecture, 424 out of 493 (86\%) sera were positive for HEV-67N showing the highest GMT of 74. In Iwate and Akita prefectures, 640 out of 738 $(86.7 \%)$ and 337 of $530(63.6 \%)$ sera were positive, respectively. The 26 GMT in Iwate was lowest. No clinical evidence of an HEV outbreak was found in any swine farms throughout the period of serum collection.

\section{$\mathrm{HI}$ antibodies to $\mathrm{HCV}-\mathrm{OC43}$}

As shown in Table 2, 2257 out of $2469(91.4 \%)$ sera were positive for HCV-OC43 with GMT of 45 in 4 prefectures. Except for Aomori Prefecture, the sera from others showed higher positivity of more than $90 \%$. In Miyagi Prefecture, 653 out of 708 (92.2\%) sera were positive and showed the highest GMT of 58 .

\section{$\mathrm{HI}$ antibodies to $\mathrm{BCV}-\mathrm{K}$}

$\mathrm{HI}$ antibodies to BCV-K were detected in 1092 out of $2469(44 \cdot 2 \%)$ sera ranging from $19 \cdot 2 \%$ in Akita to $64.9 \%$ in Aomori prefectures (Table 3). The GMT varied from 12 in Iwate to 25 in Aomori prefectures. In some farms antibodies to BCV-K were undetectable. 
Table 1. Distribution of HI antibodies to HEV-67N in swine sera in four prefectures

\begin{tabular}{|c|c|c|c|c|c|c|c|c|c|c|}
\hline \multirow{2}{*}{$\begin{array}{l}\text { Prefecture } \\
\text { (no. of } \\
\text { farms) }\end{array}$} & \multicolumn{8}{|c|}{ Number of pigs with HI titres of } & \multirow[b]{2}{*}{ Positive/tested ( $\%)$} & \multirow[b]{2}{*}{ GMT } \\
\hline & $<8$ & 8 & 16 & 32 & 64 & 128 & 256 & 512 & & \\
\hline $\begin{array}{l}\text { Aomori } \\
\text { (14) }\end{array}$ & 69 & 3 & 12 & 37 & 279 & 45 & 31 & 17 & $424 / 493(86 \cdot 0)$ & 74 \\
\hline $\begin{array}{c}\text { Iwate } \\
(16)\end{array}$ & 98 & 26 & 245 & 289 & 56 & 15 & 7 & 2 & $640 / 738(86 \cdot 7)$ & 26 \\
\hline $\begin{array}{c}\text { Akita } \\
\text { (14) }\end{array}$ & 193 & 45 & 102 & 111 & 38 & 19 & 11 & 11 & $337 / 530(63 \cdot 6)$ & 29 \\
\hline $\begin{array}{l}\text { Miyagi } \\
\text { (16) }\end{array}$ & 81 & 41 & 65 & 107 & 170 & 179 & 54 & 11 & $627 / 708(82 \cdot 1)$ & 43 \\
\hline Total $(60)$ & 441 & 115 & 424 & 544 & 543 & 258 & 103 & 41 & $2028 / 2469(82 \cdot 1)$ & 43 \\
\hline
\end{tabular}

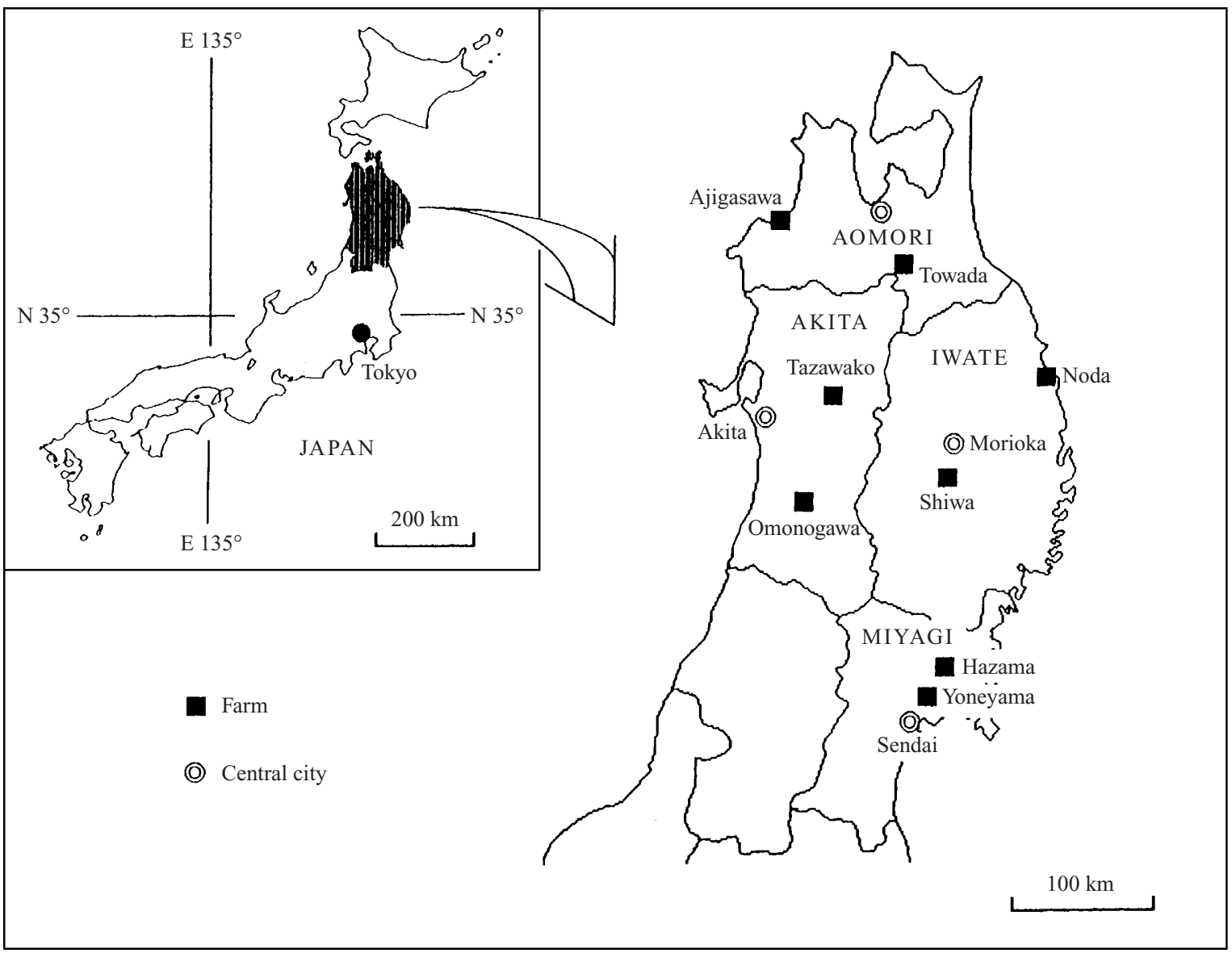

Fig. 1. Pig farms in four prefectures (Aomori, Akita, Iwate and Miyagi) in the Tohoku District of Japan.

Farms showing higher antibody titres to HEV-67N

Among 60 farms examined, those showing $100 \%$ positivity and the highest titres of HEV-67N antibody were found in each prefecture. Antibodies to HCVOC43 and BCV-K were not higher than antibody to HEV-67N. Farm Towada (Aomori), Shiwa (Iwate), Omonogawa (Akita) and Hazama (Miyagi) showed higher antibody titres to HEV-67N than to either HCV-OC43 or BCV-K (as shown in Table 4).

Farms showing higher antibody titres to $\mathrm{HCV}-\mathrm{OC43}$

The HI antibodies to HCV-OC43 in Ajisawa (Aomori), Noda (Iwate), Tazawako (Akita) and Yomeyama (Miyagi) farms had higher positive rates 
Table 2. Distribution of HI antibodies to HCV-OC43 in swine sera in four prefectures

\begin{tabular}{|c|c|c|c|c|c|c|c|c|c|c|}
\hline \multirow{2}{*}{$\begin{array}{l}\text { Prefecture } \\
\text { (no. of } \\
\text { farms) }\end{array}$} & \multicolumn{8}{|c|}{ Number of sera with HI titres of } & \multirow[b]{2}{*}{ Positive/negative (\%) } & \multirow[b]{2}{*}{ GMT } \\
\hline & $<8$ & 8 & 16 & 32 & 64 & 128 & 256 & 512 & & \\
\hline $\begin{array}{l}\text { Aomori } \\
\text { (14) }\end{array}$ & 68 & 29 & 57 & 86 & 135 & 79 & 36 & 3 & $425 / 493(86 \cdot 2)$ & $52^{*}$ \\
\hline $\begin{array}{c}\text { Iwate } \\
(16)\end{array}$ & 57 & 61 & 137 & 188 & 172 & 105 & 15 & 3 & $681 / 738(92 \cdot 3)$ & 38 \\
\hline $\begin{array}{c}\text { Akita } \\
\text { (14) }\end{array}$ & 32 & 55 & 101 & 134 & 128 & 62 & 16 & 2 & $498 / 530(94 \cdot 0)$ & 37 \\
\hline $\begin{array}{l}\text { Miyagi } \\
\text { (16) }\end{array}$ & 55 & 45 & 63 & 109 & 230 & 143 & 58 & 12 & $653 / 708(92 \cdot 2)$ & 59 \\
\hline Total $(60)$ & 212 & 190 & 358 & 517 & 665 & 382 & 125 & 20 & $2257 / 2469(91 \cdot 4)$ & 45 \\
\hline
\end{tabular}

Table 3. Distribution of HI antibodies to $B C V$ - $K$ in swine sera in four prefectures

\begin{tabular}{|c|c|c|c|c|c|c|c|c|}
\hline \multirow{2}{*}{$\begin{array}{l}\text { Prefecture } \\
\text { (no. of } \\
\text { farms) }\end{array}$} & \multicolumn{6}{|c|}{ Number of sera with $\mathrm{HI}$ titres of } & \multirow[b]{2}{*}{ Positive/negative (\%) } & \multirow[b]{2}{*}{ GMT } \\
\hline & $<8$ & 8 & 16 & 32 & 64 & 128 & & \\
\hline $\begin{array}{l}\text { Aomori } \\
\text { (14) }\end{array}$ & 173 & 41 & 105 & 116 & 47 & 11 & $320 / 493(64 \cdot 9)$ & $25^{*}$ \\
\hline $\begin{array}{c}\text { Iwate } \\
\text { (16) }\end{array}$ & 480 & 117 & 112 & 28 & 1 & & $258 / 783(35 \cdot 0)$ & 13 \\
\hline $\begin{array}{c}\text { Akita } \\
\text { (14) }\end{array}$ & 429 & 31 & 56 & 12 & 3 & & $102 / 530(19 \cdot 2)$ & 15 \\
\hline $\begin{array}{l}\text { Miyagi } \\
\text { (16) }\end{array}$ & 296 & 136 & 134 & 111 & 27 & 4 & $412 / 708(58 \cdot 2)$ & 17 \\
\hline Total (60) & 1377 & 325 & 407 & 267 & 78 & 15 & $1092 / 2469(44 \cdot 2)$ & 18 \\
\hline
\end{tabular}

Table 4. Swine farms showing higher antibody titres to HEV-67N

\begin{tabular}{|c|c|c|c|c|c|c|c|c|c|}
\hline \multirow{2}{*}{$\begin{array}{l}\text { Farm } \\
\text { (Prefecture) }\end{array}$} & \multirow{2}{*}{$\begin{array}{l}\text { Virus } \\
\text { (Positive/tested) }\end{array}$} & \multicolumn{7}{|c|}{ Number of sera with antibody titre of } & \multirow[b]{2}{*}{ GMT } \\
\hline & & 8 & 16 & 32 & 64 & 128 & 256 & 512 & \\
\hline \multirow{3}{*}{$\begin{array}{l}\text { Towada } \\
\text { (Aomori) }\end{array}$} & $\operatorname{HEV}(73 / 73)$ & 1 & 2 & 5 & 12 & 16 & 20 & 17 & $158^{*}$ \\
\hline & HCV (20/73) & 2 & 15 & 2 & 1 & & & & 17 \\
\hline & $\mathrm{BCV}(10 / 73)$ & 1 & 7 & 2 & & & & & 17 \\
\hline \multirow{3}{*}{$\begin{array}{l}\text { Shiwa } \\
\text { (Iwate) }\end{array}$} & HEV (27/27) & 1 & 1 & 2 & 7 & 11 & 4 & 1 & 94 \\
\hline & HCV (27/27) & & 4 & 8 & 9 & 4 & 2 & & 52 \\
\hline & BCV $(20 / 27)$ & 9 & 11 & & & & & & 12 \\
\hline \multirow{3}{*}{$\begin{array}{l}\text { Omonogawa } \\
\text { (Akita) }\end{array}$} & HEV (42/42) & 1 & 6 & 8 & 6 & 10 & 2 & 9 & 86 \\
\hline & HCV $(42 / 42)$ & & 12 & 12 & 9 & 3 & 4 & 2 & 47 \\
\hline & $\mathrm{BCV}(11 / 42)$ & 8 & 2 & 1 & & & & & 10 \\
\hline \multirow{3}{*}{$\begin{array}{l}\text { Hazama } \\
\text { (Miyagi) }\end{array}$} & HEV $(84 / 84)$ & & 1 & 5 & 10 & 15 & 43 & 10 & 178 \\
\hline & HCV $(63 / 84)$ & 3 & 16 & 29 & 21 & 7 & 7 & 7 & 43 \\
\hline & $\mathrm{BCV}(32 / 84)$ & 14 & 10 & 7 & 1 & & & & 14 \\
\hline
\end{tabular}

and antibody titres than did those to HEV-67N and BCV-K (Table 5). Especially, Farm Yoneyama showed the highest antibody titres to HCV-OC43; the
GMT for HCV-OC43 was 200 in 42 swine sera. That GMT was higher than the GMT of 45 in 2257 of 2469 sera samples from other farms (Table 2), and also 
Table 5. Swine farms showing high antibody titres to $\mathrm{HCV}-\mathrm{OC43}$

\begin{tabular}{|c|c|c|c|c|c|c|c|c|c|c|}
\hline \multirow{2}{*}{$\begin{array}{l}\text { Farm } \\
\text { (Prefecture) }\end{array}$} & \multirow{2}{*}{$\begin{array}{l}\text { Virus } \\
\text { (Positive/tested) }\end{array}$} & \multicolumn{8}{|c|}{ Number of sera with antibody titre of } & \multirow[b]{2}{*}{ GMT } \\
\hline & & 8 & 16 & 32 & 64 & 128 & 256 & 512 & 1028 & \\
\hline \multirow{3}{*}{$\begin{array}{l}\text { Ajisawa } \\
\text { (Aomori) }\end{array}$} & HEV $(25 / 30)$ & 4 & 9 & 8 & 3 & 1 & & & & $23^{*}$ \\
\hline & $\operatorname{HCV}(30 / 30)$ & & 2 & 7 & 6 & 12 & 3 & & & 75 \\
\hline & $\operatorname{BCV}(13 / 30)$ & 12 & & & 1 & & & & & 9 \\
\hline \multirow{3}{*}{$\begin{array}{l}\text { Noda } \\
\text { (Iwate) }\end{array}$} & HEV (95/121) & 21 & 37 & 26 & 8 & 3 & & & & 20 \\
\hline & $\operatorname{HCV}(120 / 121)$ & & 11 & 20 & 37 & 38 & 14 & & & 95 \\
\hline & $\operatorname{BCV}(39 / 121)$ & 32 & 6 & 1 & & & & & & 10 \\
\hline \multirow{3}{*}{$\begin{array}{l}\text { Tazawako } \\
\text { (Akita) }\end{array}$} & HEV (15/19) & 3 & 5 & 4 & 3 & & & & & 22 \\
\hline & $\operatorname{HCV}(19 / 19)$ & & 5 & 6 & 2 & 1 & 3 & 2 & & 59 \\
\hline & BCV (0/19) & & & & & & & & & \\
\hline \multirow{3}{*}{$\begin{array}{l}\text { Yoneyama } \\
\text { (Miyagi) }\end{array}$} & HEV (42/42) & 5 & 7 & 19 & 6 & & 2 & 3 & & 36 \\
\hline & $\operatorname{HCV}(42 / 42)$ & & 1 & 1 & 1 & 13 & 12 & 11 & 1 & 200 \\
\hline & $\mathrm{BCV}(42 / 42)$ & 9 & 19 & 10 & 3 & 1 & & & & 19 \\
\hline
\end{tabular}

Table 6. Cross-HI test among HEV-67N, HCV-OC43, BCV-K and their antisera and anti-TGEV

\begin{tabular}{lcccc}
\hline \hline \multirow{4}{*}{ Virus } & \multicolumn{3}{l}{ Antiserum against } \\
\cline { 2 - 4 } & HEV-67N & HCV-OC43 & BCV-K & TGEV \\
\hline HEV-67N & $1: 512^{*}$ & $1: 16$ & $1: 8$ & $<1: 2$ \\
HCV-OC43 & $<1: 2$ & $1: 1024$ & $<1: 2$ & $<1: 2$ \\
BCV-K & $1: 8$ & $<1: 2$ & $1: 1024$ & $<1: 2$ \\
\hline \hline
\end{tabular}

* Final serum dilution showing HI.

higher than those for HEV-67N and BCV-K. In contrast, Farm Hazama (Miyagi), located about $10 \mathrm{~km}$ north from Farm Yoneyama, showed the highest GMT of 178 for HEV-67N while the GMT for HCV-OC43 was 43 (as shown in Table 4).

\section{Cross-reactivity among three viruses}

To see the possibility of cross-reactivity among viruses used as HA antigen, cross-HI tests were performed. The viruses reacted with homologous antisera not with anti-TGEV guinea-pig serum. Anti-HCV-OC43 mouse serum weakly reacted with $\mathrm{BCV}-\mathrm{K}$, and mouse antiserum to BCV-K weakly reacted with HEV-67N. Anti-HCV-OC43 serum weakly reacted with HEV$67 \mathrm{~N}$.

\section{DISCUSSION}

In 1974, Hirai and colleagues [11] conducted the serological survey on HEV infection in pigs in Japan, revealing that about $50 \%$ of all pigs in Japan and $27 \%$ those in the Tohoku District were positive for
HEV-67N. In the present study, $82 \%$ of animals in Tohoku District were shown to be positive for HEV$67 \mathrm{~N}$. This positivity rate was higher than those reported in Canada [8], England [6], North Ireland [9], Taiwan [10] and USA [12]. All the animals of Farm Hazama were positive for HE-67N having the highest GMT of 178. No clinical disease was observed in any of the 60 farms examined, indicating that HEV might be perpetuating as unapparent form of infection.

Hirasawa and colleague [13] isolated four strains of HEV from 5-month-old pigs with respiratory disease from two farms showing seropositivity of $90 \%$ for HEV-67N. After inoculation of the isolates into colostrum-deprived piglets, respiratory illness was produced but no vomiting.

Interestingly, $\mathrm{HI}$ antibodies to $\mathrm{HCV}-\mathrm{OC} 43$ were detected in pigs at a higher incidence than antibodies to HEV-67N and BCV-K. Yoneyama and Hazama farms, $10 \mathrm{~km}$ apart from each other, showed different antibody patterns, suggesting that HCV-OC43 or antigenitically related virus(es) might be responsible for HI antibodies to HCV-OC43 in Farm Yoneyama. 
These findings showed that transmission of the virus among humans and pigs might occur due to close contact.

Kaye and colleagues [18] reported antigenic relationship between HCV-OC43 and HEV-67N and antibody response in human and animal sera. Both viruses have been shown to react with hyperimmune homologous sera. Sera from veterinary students and meat-packers show higher titres of HI antibodies to HEV-67N than those of college students, while swine sera appear negative for $\mathrm{HCV}-\mathrm{OC} 43$ but $38 \%$ positive for HEV-67N.

The cross-HI tests suggested that antibody responses of swine sera to HEV-67N, HCV-OC43 and BCV-K might not be due to TGEV infection, and to PEDV infection because PEDV was reported to not cross-react with HEV and TGEV by Pensaert and colleagues [19] so that antibody response to HCVOC43 might result from HCV-OC43 or antigenically related virus infection in swine.

Kaye and colleagues [20] reported the prevalence of antibodies to HCV-OC43 in children. Similarly, Kawana and Matsumoto [21] showed that $60-80 \%$ of 3- to 5-year-old children in Morioka were positive for $\mathrm{HI}$ antibodies to HCV-OC43, and that 6- to 9-yearold children or adults had positivities of $80-100 \%$. These results showed that HCV was perpetuated in humans in Morioka district. These and our results also suggest the possibility that swine might become infected with $\mathrm{HCV}$ from unapparently infected humans.

The positivity and titres of antibodies to BCV-K were negative or much lower than titres to $\mathrm{HCV}$ OC43. As described above, cross-reactivity experiments did not suggest that antibodies to BCV-K in swine might be the result of an infection with HEV or TGEV, and could be established by BCV infection after contact with cattle-keeping farmers. Because Storz and Rott [22] reported the inter-species transmission of BCV from experimentally infected calves to man, and Zhang and colleagues [23] demonstrated that a haemagglutinating coronavirus isolated from a diarrhoeic child was antigenically and genomically more closely related to $\mathrm{BCV}$ than to $\mathrm{HCV}-\mathrm{OC} 43$.

\section{REFERENCES}

1. Wege H, Siddell ST, ter Meulen V. The biology and pathogenesis of cornaviruses. Curr Top Microbiol Immunol 1982; 99: 165-200.

2. Roe CK, Alexander TJL. A disease of nursing pigs previously unreported in Ontario. Conad J Comp Med 1958; 22: 305-7.
3. Mitchell D. Encephalomyelitis of swine caused by hemagglutinating virus. I. Case histories. Res Vet Sci $1963 ; 4: 506-10$.

4. Greig AS, Girard A. Enchephalomyelitis of swine caused by a hemagglutinating virus. II. Virological studies. Res Vet Sci 1963; 4: 511-7.

5. Alexander TJL, Sanders CN. Vomiting and wasting disease of piglets. Vet Rec 1969; 84: 178.

6. Cartright SF, Lucas M, Cavill JP, Gush AF, Blandford TB. Vomiting and wasting disease of piglets. Virological and epidemiological studies. Vet Rec 1970; 86: 278-9.

7. Mengeling WL, Bloothe AD, Richte AE. Characterization of coronavirus (strain $67 \mathrm{~N}$ ) of pigs. Am J Vet Res 1972; 33: 297-308.

8. Girard A, Greig AS, Mitchell D. Encephalomyelitis of swine caused by a hemagglutinating virus. III. Serological studies. Res Vet Sci 1964; 5: 294-302.

9. Mcferren JB, Clarke JK, Cornner TJ, Norx ER. Serological evidence of the presence of hemagglutinating encephalomyelitis virus in Northern Ireland. Vet Rec 1971; 88: 339-40.

10. Chang CN, Hsu FS, Shen YM, Yen CC. A serological survey on hemagglutinating encephalomyelitis virus infection in pigs of Taiwan Sugar Corporation. Taiwan; Annual Research Report of Animal Research Institute. Taiwan Sugar Corporation, 1978: 157-63.

11. Hirai K, Chang CN, Shimakura S. A serological survey on hemagglutinating encephalomyelitis virus infection in Japan. Jpn J Vet Sci 1974; 36: 375-82.

12. Mengeling WL. Incidence of antibody for hemagglutinating encephalomyelitis virus in serum from swine in the United States. Am J Vet Res 1975; 36: 821-5.

13. Hirahara T, Yasuhara H, Kodama K, Nakai M, Sasaki $\mathrm{N}$. Isolation of hemagglutinating encephalomyelitis virus from respiratory tract of pig in Japan. Jpn J Vet Sci 1987; 49: 85-93.

14. Takahashi A, Inaba Y, Sato K, et al. Epizootic dairrhea of adult cattle associated with coronavirus like agent. Vet Microbiol 1980; 5: 151-4.

15. McIntosh K, Dees JH, Becker WB, Kapikian AZ, Chanock RM. Recovery in tracheal organ cultures of novel viruses from patients with respiratory disease. Proc Natl Acad Sci 1967; 57: 933-40.

16. Hirano N, Ono K, Takasawa H, Murakami T, Haga S. Replication and plaque formation of swine hemagglutinating encephalomyelitis virus $(67 \mathrm{~N})$ in swine cell line, SK-K culture. J Virol Meth 1990; 27: 91-100.

17. Hirano N, Sada Y, Tsuchiya K, Ono K, Murakami T. Plaque assay of bovine coronavirus in BEK-1 cells. Jpn J Vet Sci 1985; 47: 679-81.

18. Kaye HS, Yarbrough WR, Reed CJ, Harrison AK. Antigenic relationship between human coronavirus strain OC43 and hemagglutinating encephalomyelitis virus $67 \mathrm{~N}$ strain. Antibody responses in human and animal sera. J Infect Dis 1977; 135: 201-9.

19. Pensaert MB, Debouck P, Reynolds DJ. An immunoelectron microscopic and immunofluorescent study on the antigenic relationship between the coronavirus-like agent, CV777, and several coronaviruses. Arch Virol 1981; 68: 45-52.

20. Kaye HS, March HB, Dowdle WR. Seroepidemiologic 
survey of corona-virus (strain OC 43) related infections in a children's population. Am J Epidemiol 1971; 94: 43-9.

21. Kawana R, Matsumoto I. Clinical virology of rhinovirus and coronavirus infection in man. Modern Media 1975; 21 : 158-72.

22. Storz J, Rott R. Reactivity of antibodies in human serum with antigens of an enteropathogenic bovine coronavirus. Med Microbiol Immunol 1981; 169: 169-76.

23. Zhang XM, Herbst W, Kousoulas KG, Storz J. Biological and genetic characterization of a hemagglutinating coronavirus isolated from a diarrhoeic child. J Med Virol 1994; 44: 152-61. 